\title{
Assessment of Meteorological Drought in Climate Variability Context within the Comoe River Transboundary Watershed
}

\author{
Ismaïla Ouattara ${ }^{1}$, Léréyaha Coulibaly ${ }^{1}$, Koffi Abdelaziz Kouakou², Amidou Dao ${ }^{3}$, \\ Dabissi Djibril Noufé3, Bamory Kamagaté1,3, Issiaka Savané ${ }^{3}$ \\ ${ }^{1}$ UFR Sciences Géologiques et Minières (SGM), Université de Man, Man, Côte d'Ivoire \\ ${ }^{2}$ Département de Géosciences, Université Péléforo Gon Coulibaly (UPGC), Korhogo, Côte d'Ivoire \\ ${ }^{3}$ Laboratoire Géosciences et Environnement (LGE), UFR-SGE, Université Nangui Abrogoua (UNA), \\ Abidjan, Côte d'Ivoire \\ Email: *ismael2x@yahoo.fr
}

How to cite this paper: Ouattara, I., Coulibaly, L., Kouakou, K.A., Dao, A., Noufé, D.D., Kamagaté, B. and Savané, I. (2022) Assessment of Meteorological Drought in Climate Variability Context within the Comoe River Transboundary Watershed. Atmospheric and Climate Sciences, 12, 1-17. https://doi.org/10.4236/acs.2022.121001

Received: October 8, 2021

Accepted: November 5, 2021

Published: November 8, 2021

Copyright $\odot 2022$ by author(s) and Scientific Research Publishing Inc. This work is licensed under the Creative Commons Attribution International License (CC BY 4.0).

http://creativecommons.org/licenses/by/4.0/

\begin{abstract}
In the context of climate variability resulting in a decrease in rainfall with a severe drought, a spatio-temporal study of this phenomenon remains imperative for the efficient management of water resources. This paper aims to assess the long-term rainfall drought trend and breakpoints within the Comoe River watershed. From monthly rainfall data series (1960-2000), Standardized Precipitation Index (SPI) values were calculated for a time scale of 3 months (SPI.3). Statistical tests for breaks (CUSUM, and t-Student) and trends (Man-Kendall and Linear Regression) as well as the Sen' slope method for estimating the magnitude of trends was applied. The breaks dates observed are mostly located after the 1970s. Based on SPI.3 values below the threshold of 0.84 chosen as an indicator of drought, rarely has more than half of the catchment area been affected by drought. The average watershed affected is about $20 \%$ over the study period (1960-2000). The most representative years, in terms of spatial expansion of the drought, in decreasing order of importance are: 1983, 1992, 1972 and 1982. The years 1982 and 1983 stand out for their exceptional condition, as the drought-affected $50 \%$ to $90 \%$ of the total catchment area. SPI.3 series from 1960 to the various break dates recorded slopes between -0.01 and 0.00 with a slight drought trend for most of the catchment. After the break periods, almost the entire northern part of the ba$\sin$ is characterized by slight moisture with Sen's slopes between 0.000 and 0.005 . The southern part will remain slightly subject to normal rainfall conditions.
\end{abstract}




\section{Keywords}

Climate Variability, Drought, SPI.3-Index, Sen's Slope, Comoe River Basin

\section{Introduction}

Life sustainability is not possible without it. The abundance of water brings comfort, whereas in its scarceness life becomes miserable. Human beings are dependent on water in almost every activity within the environment. If water is scarce or not available in sufficient quantities at a location, then human beings migrate to better water resource locations, which are riverbanks, lakes, seashores, oases, or shallow groundwater reservoirs. The evolution and development of any civilization have roots in water-related management activities. Such activities are the start of social gatherings, cultures, and civilizations. Any civilization is under the pressure of internal and external impacts and urges for food security, which cannot be achieved without water security. Water resources have been and still are under internal and external pressures. Drought is a creeping natural hazard that results from a deficiency of precipitation (runoff, soil moisture) from the long-term average (over at least 30 years), which is referred to as a normal value [1]. One of the main consequences of multiyear drought periods is severe famine, such as the one associated with the drought in the Sahel in the 1980s, causing many casualties and important socio-economic losses. The people in Africa who live in drought-prone areas are vulnerable to the direct impacts of droughts (e.g., famine, death of cattle, soil salinization), as well as indirect impacts (e.g., illnesses such as cholera and malaria) [2]. Agriculture in Africa and more precisely in sub-Saharan Africa is almost $95 \%$ rain-fed. It, therefore, remains very vulnerable to fluctuations in needs [3].

The water sector is strongly influenced by, and sensitive to, periods of prolonged drought conditions in a continent with limited water storage infrastructure. Natural water reservoirs such as lakes experience a marked interannual water level fluctuation related to rainfall interannual variability [4]. Large changes in hydrology and water resources linked to climate variability have led to water stress conditions in human and ecological systems in a number of African countries [5] [6]. The Comoe River watershed is a transboundary basin located in West Africa. Water resources of this basin are, in fact, shared between Côte d'Ivoire, Burkina Faso, Ghana and Mali. The climatic variability affecting this area of Africa is characterized by a decrease of around $20 \%$ to $30 \%$ in rainfall and an even greater drop in the flow of surface water [7] [8]. Based on this observation, what could be the impact of this climatic variability on the spatio-temporal manifestation of meteorological drought in the watershed? Trying to answer this question will guide us throughout this research work.

Several drought indices in the literature have been used to appreciate the meteorological drought. Most of these indices depend on the time scale. Indices in 
Heim [9] work were used. Many methods are used for the characterization of rainfall drought, such as, the traditional one: the Nicholson index, which imposes a 1-year scale and does not require adjustment. Besides the Bhalme and Mooley Drought index which is simple and less complex. Also, the Standardized Precipitation-Evapotranspiration Index (SPEI) associates, in addition to rain, evapotranspiration as input data for calculations. There is the SPI (Standardized Precipitation Index) by [10]. This index is very flexible and less demanding in terms of input data, which earned it recognition from the World Meteorology Organization [11]. Some drought indices specifically reflect one type of impact or application, while others can be configured to correspond to varying impacts and thus drought type. For example, SPI, which is a meteorological drought, can be deployed for longer time scales to reflect agricultural and hydrological droughts/impacts [12].

Drought differs from other natural hazards (e.g., floods, tropical cyclones, and earth-quakes) in several ways. First, since the effects of drought often accumulate slowly over a considerable period of time and may linger for years after the termination of the event, the onset and end of the drought are difficult to determine. Because of this, drought is often referred to as a creeping phenomenon [13]. Among the natural hazards, droughts possess certain unique features; in addition to delayed effects, droughts vary by multiple dynamic dimensions including severity and duration, which in addition to causing a pervasive and subjective network of impacts makes them difficult to characterize. In order to manage drought, drought characterization is essential enabling both retrospective analyses (e.g., severity versus impacts analysis) and prospective planning (e.g., risk assessment) [12]. This scientific paper is part of a retrospective framework. The aim of the study is to assess the impact of climate variability on the spatio-temporal variation of meteorological drought using the SPI index. Knowledge of the past manifestations of this phenomenon is of the capital interest because it allows firstly making a quantified assessment of socio-economic losses and secondly to set up models for the management of future droughts based on past events.

\section{Location and Climate of Study Area}

The Comoe River watershed is a transboundary basin shared by Côte d'Ivoire, Burkina Faso, Ghana and Mali (Figure 1). It is located between latitudes $5^{\circ} 02^{\prime}$ and $11^{\circ} 04^{\prime}$ North and longitudes $2^{\circ} 07^{\prime}$ and $5^{\circ} 81^{\prime}$ West of the geographic coordinate system (WGS 84, zone $30 \mathrm{~N}$ ).

The study area is located in the eastern part of Côte d'Ivoire. It is bounded in the north by the Niger basin, in the northeast by the Volta Basin, in the southeast by the Bia basin, in the west by the Bandama basin and in the Agnéby coastal basin. In the southern part, it's bounded by the Atlantic Ocean in the Gulf of Guinea [14]. Following a common method already used by [15], considering the limit of $100 \mathrm{~mm}$ of monthly rainfall to separate the wet season from the dry season, the following observations are made: 1) the South of the basin, represented 


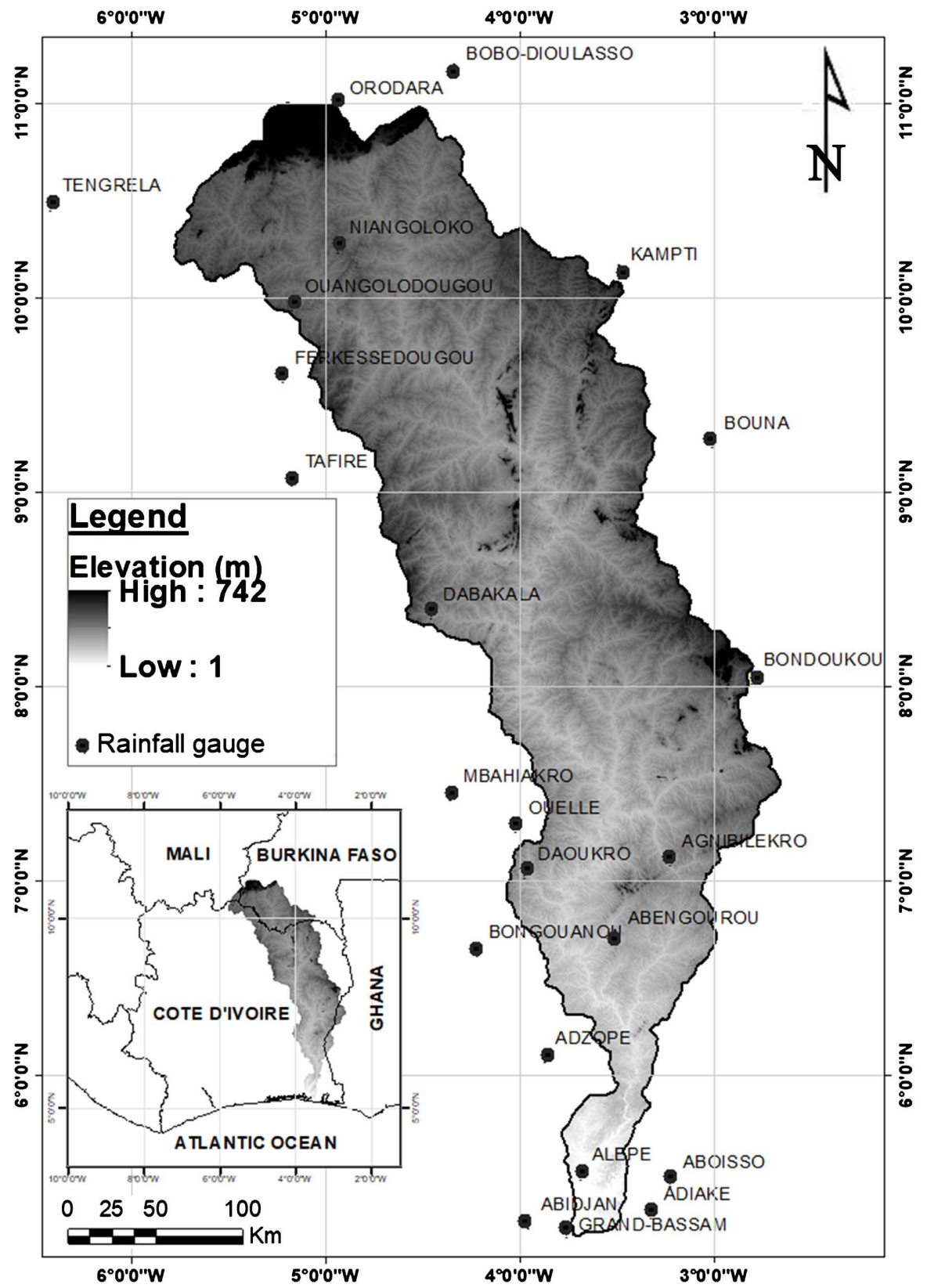

Figure 1. Location and rainfall gauges of Comoe River watershed in West Africa.

by Abidjan's station, presents in median values a big rainy season of 5 months (March-July). It is separated by a short-wet transition period of 2 months (August-September), and a second rainy season of 3 months (October-December), itself finally separated, from a largely dry season of 2 to 3 months (December to February); 2) the center of the basin, represented by the Dimbokro station inland, the first rainy season lasts at the limit between 4 and 5 months (March-July, the median of July is $82.9 \mathrm{~mm}$ ). This period is separated by a wet transition of one month (August), and a small rainy season that lasts more than 2 months (October-November), but separated from a largely dry season of 4 months (November to February); 3) the North (Bouna station), on the other hand, the monomodal 
regime has taken precedence over the bimodal regime. The only rainy season that lasts 6 to 7 months (April-October because if the median of April is 90.7 $\mathrm{mm}$, that of October is $98.2 \mathrm{~mm}$ ) is opposed to a long dry season of about 5 to 6 months (October/November to March). As one moves from the South to the North, the coastal areas and their immediate hinterland appear much more advantageous than those in the transition zone in terms of rainfall abundance. The central regions are more favored than those of the North in sub-Sudanian zones with unimodal rainfall [16] as noted by [17].

\section{Data and Methods}

\subsection{Rainfall Database}

Study data are essentially monthly rainfall data. The rainfall gauges are irregularly arranged on the basin and most of them are outside the basin (Figure 1). However, they influenced the meteorological functioning of the basin on the basis of Thiessen polygons. Data quality and spatialization are relatively good. However, they have a few gaps (which were filled). Also, to obtain a sufficient amount of data for the drought spatialization, the data used is from 1960 to 2000. Thus, the rainfall data of the study have, at least, a time series of 40 years. In addition to these rainfall gauges, Abidjan's rainfall station was used for the needs of the study (the measurement network is less dense). The hydroclimatic data in Côte d'Ivoire were made available by SODEXAM (Société d'Exploitation et de Développement Aéroportuaire, Aéronautique et Météorologique). Some rainfall gauges located in Burkina Faso, from IRD (Institut de Recherche pour le Développement) data-base, were used. Figure 1 shows the different rainfall gauges and their geographical positions.

\subsection{Standardized Precipitation Index (SPI) Calculation}

Highlighted by the WMO as a starting point for meteorological drought monitoring, recommended by WMO in 2009 as the main indicator for monitoring drought, easy to calculate and applicable in all climates, free software is available for calculation. The Standardized Precipitation Index (SPI) was developed by [10] to serve as a "versatile tool in drought monitoring and analysis". The SPI calculation for any location is based on the long-term precipitation record for the desired period. This long-term record is fitted to a probability distribution, which is then transformed into a normal distribution so that the mean SPI for the location and desired period is zero [18]. Positive SPI values indicate greater than median precipitation, and negative values indicate less than median precipitation. Since SPI is normalized, wetter and drier climates can be represented in the same way. Although SPI can monitor wet periods, it is typically used to assess the length and magnitude of drought events. Reference [18] found the gamma distribution to fit well to the climatological precipitation time series. The gamma distribution is defined by its frequency or probability density function (Equation (1)). 


$$
g(x)=\int_{0}^{x} f(x) \mathrm{d} x=\frac{1}{\beta^{\alpha} \Gamma(\alpha)} \int_{0}^{x} x^{\alpha-1} \mathrm{e}^{-\left(\frac{x}{\beta}\right)} \mathrm{d} x
$$

In which $\alpha$ and $\beta$ are the shape and scale parameters respectively, $x$ is the precipitation amount and $\Gamma(\alpha)$ is the gamma function. Parameters $\alpha$ and $\beta$ of the gamma PDF are estimated for each station and for each time scale of interest (1, $3,6,9,12$ months, etc.). With $n$ the number of observations, maximum likelihood estimations of $\alpha$ and $\beta$ are (Equation (2)):

$$
\alpha=\frac{1}{4 A}\left(1+\sqrt{1+\frac{4 A}{3}}\right), \beta=\frac{\bar{x}}{\alpha}, \quad \text { where } A=\ln (\bar{x})-\frac{\sum \ln (x)}{n}
$$

The resulting parameters are then used to find the cumulative probability of an observed precipitation event for the given month and time scale for the location in question. Since the gamma function is undefined for $x=0$ and a precipitation distribution may contain zeros, the cumulative probability becomes (Equation (3)):

$$
H(x)=q+(1-q) F(x)
$$

In which $q$ is the probability of zero precipitation and $F(x)$ is the cumulative probability of the incomplete gamma function. If $m$ is the number of zeros in a precipitation time series, then $q$ can be estimated by $m / n$. The cumulative probability $H(x)$, is then transformed to the standard normal random variable $z$ with mean 0 and variance of 1 , which is the value of the SPI. According to the SPI, a drought event occurs when the index continuously reaches an intensity of -1.0 or less. The event ends when the SPI becomes positive. Each drought event, therefore, has a duration defined by its beginning and end, and intensity for each month that the event continues [19]. The SPI can track drought on multiple time scales. It is usually computed with five running time intervals, i.e., 1, 3, 6, 9, and 12-months, but the index is flexible with respect to the period chosen, which depends on the amount of information needed by the researcher. Moreover, being a standardized index, the SPI is particularly suited to compare drought conditions among different time periods and regions with different climatic conditions. The SPI is the number of standard deviations that the observed value would deviate from the long-term mean, for a normally distributed random variable. Table 1 gives an interpretation of the resultant values.

\subsection{Statistical Tests for Breaks and Trends}

The purpose of the trend and break tests in the SPI.3 series is to assess the temporal distribution of the chronicles in the Comoe basin. In fact, there are many parametric and non-parametric methods cited by authors such as [20]. The methods selected among many others for determining breaks, trends in a series are based on the work of Krishna [21]. The most effective non-parametric tests for breaks in series are the Mann-Whitney test [22], the Free-CUSUM test and the parametric t-Student test. As for trend assessment, the non-parametric Mann- 
Table 1. Different drought classes according to SPI values [10].

\begin{tabular}{cc}
\hline SPI values & Classification \\
\hline $2.00>$ & Extremely wet \\
$1.50-1.99$ & Very wet \\
$1.00-1.49$ & Moderately wet \\
$0.99--0.99$ & Near normal \\
$-1.00--1.49$ & Moderately dry \\
$-1.50--1.99$ & Severely dry \\
$-2.00<$ & Extremely dry \\
\hline
\end{tabular}

Standardized Precipitation Index (SPI) has been calculated using version 1.5 of the DrinC software.

Table 2. Different statistical tests used in the study.

\begin{tabular}{ccc}
\hline Test & Break detection & Trend detection \\
\hline Non-parametric & Free CUSUM distribution & Mann-Kendall \\
Parametric & t-Student & Linear regression \\
\hline
\end{tabular}

Kendall test and the parametric regression test have proved effective in several studies of trend characterization in hydroclimatic series [20] [23]. The different tests used in this study are listed in Table 2, and the related statistics are in [18]. Hydrological series are rarely symmetrical and the normality condition is not always verified for the application of parametric tests. In this case, resampling techniques are used.

\subsection{Resampling (Block Bootstrap/Block Resampling)}

In order to avoid the application of parametric and non-parametric tests, i.e., normality and independence, "resampling" methods were used. Resampling techniques are a particularly flexible approach as they can be used even when the data are auto-correlated or cyclical, using block bootstrap or block resampling techniques [20] [24]. In this approach, the original data (the SPI.3 values in the study) are resampled in predetermined blocks for a large number of times to estimate the significance of the observed statistical test.

\subsection{Estimation of Drought Amplitude (Sen's Slope)}

In the present study, the linear trend is analyzed and the magnitude of the trend is estimated through Sen's slope method used by [25]. Sen's median slopes method gives a robust estimate of the tendency [22] [26]. It calculates the slope (Equation (4)) as a change in the value of the distribution in a given time interval.

$$
Q^{\prime}=\frac{x_{t^{\prime}}-x_{t}}{t^{\prime}-t}
$$

$Q^{\prime}$ : Slope between data points $x_{t^{\prime}}$ and $x_{t}$; 
$x_{t^{\prime}}$ : value of $x$ at $t^{\prime}$

$x_{t}$ : value of $x$ at $t$.

Sen's slope estimator is expressed as the median of the slopes (Equations (5) and (6)).

$$
\left\{\begin{array}{l}
Q=Q_{\left(\frac{N+1}{2}\right)}^{\prime} \quad \text { if } N \text { is even } \\
Q=\frac{Q_{\left(\frac{N}{2}\right)}^{\prime}+Q_{\left(\frac{N}{2}\right) / 2}^{\prime}}{2} \text { if } N \text { is uneven }
\end{array}\right.
$$

where $N$ is the number of slopes calculated.

Finally, the slope is examined by the bilateral test with a standard deviation of $100(1-\alpha) \%$, and the true slope is obtained by a non-parametric test.

\section{Results and Discussion}

\subsection{Basin Area Affected by Drought}

Based on the SPI.3 index values below the threshold of 0.84 , chosen as the drought indicator, Figure 2 shows the area of the watershed affected by drought. Rarely, more than half of the watershed area has been affected by drought. The mean surface area of the affected Comoe watershed is about $20 \%$ during the study period (1960-2000). The period from 1980 to 1983 is characterized by exceptional events. Drought is spreading about $50 \%$ to $90 \%$ of the total area of the watershed. The year 1983 corresponds to the period where the large surface of the basin was affected. Sorting is based on months when more than half of the watershed area experienced drought. The corresponding duration is approximately 4 years and a half, i.e., 54 months out of 480 months. This corresponds to $11.25 \%$ of the study period during which the drought-affected more than half of the study area. The most representative years, in terms of spatial expansion of drought, in descending order are 1983, 1992, 1972, and 1982. Figure 3 illustrates the areas of the basin that were most affected during these four exceptional years.

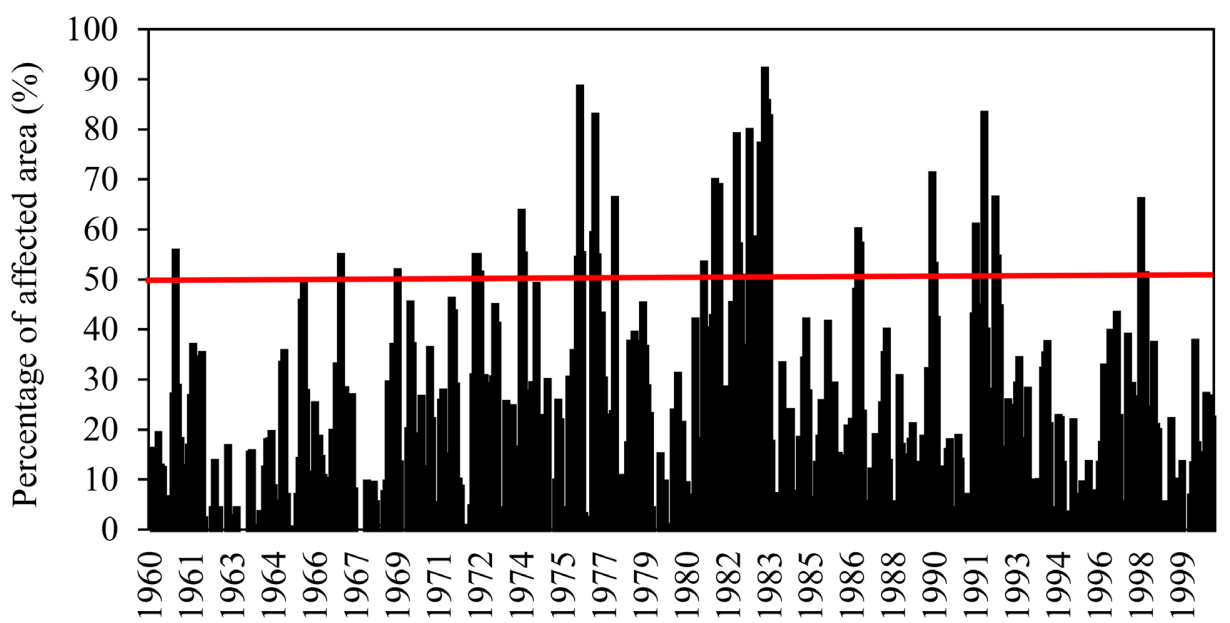

Figure 2. Temporal evolution of the percentage of the Comoe Basin area affected by the drought from 1960 to 2000. 

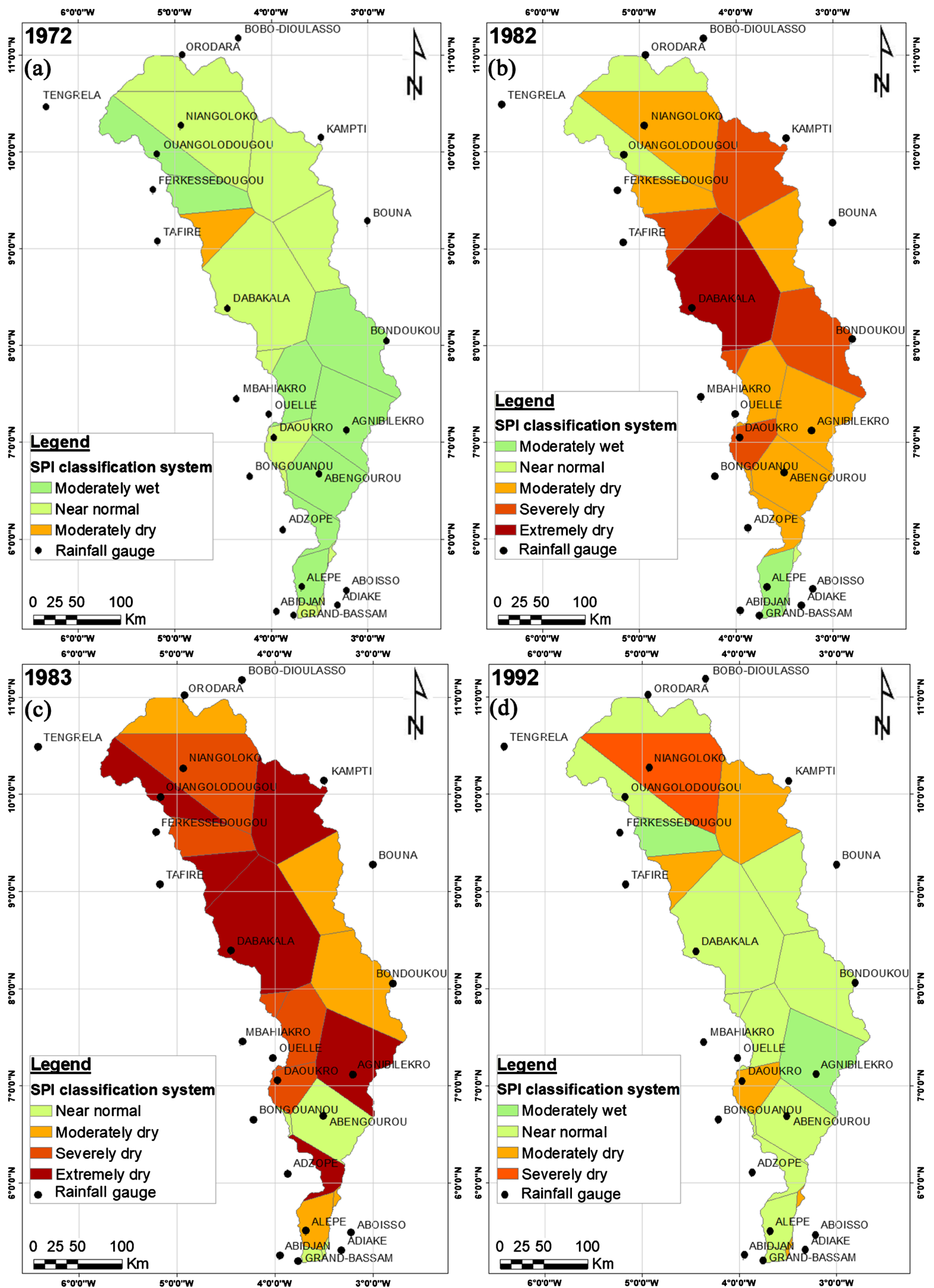

Figure 3. Spatio-temporal evolution of the intensity of drought episodes within the Comoe Basin: (a) in 1972; (b) in 1982; (c) in 1983 and (d) in 1992. 


\subsection{Emphasis on the Exceptional Years of Drought}

Although the 1970s saw the beginning of a few events of drought, the 1980s marked the beginning of episodes of extreme drought and more spatially extended (Figure 3). In 1972 (Figure 3(a)), the drought settled in the central and northern parts of the basin, excepting the northwest with stations like Ferkessédougou and Ouangolodougou. Between the central and the northern part of the catchment, only a tiny part of the basin around Daoukro and Grand-Bassam is affected. Only around Tafire station, the drought is of "moderate" type. A decade later, starting in 1982, the drought spread more in space terms and also increased in intensity (Figure 3(b)). The central-eastern and southern parts will be under the influence of moderate to weak drought. Only the extreme south with cities like Alépé, Adiaké, Aboisso and Grand-Bassam and the north with towns like Orodara and Ouangolodougou are spared. The year 1983 recorded the most dramatic drought because it affected almost the entire basin with acuteness. In addition, this year has been characterized by intense to extreme droughts (Figure 3(c)). From 1992 onwards, the drought has been reduced to a lesser extent. Only the extreme north has experienced intense drought. There is also a recovery in rainfall around Ferkessédougou and Agnibilékro (Figure 3(d)).

\subsection{Meteorological Drought Length per Rainfall Gauges}

The occurrence of the different drought durations at the threshold SPI. $3<-0.84$ is shown in Figures 4(a)-(d). Stations have a duration that varies between 1 and 5 months mostly. 1, 2 and, to a lesser extent, 3 months are the most frequent
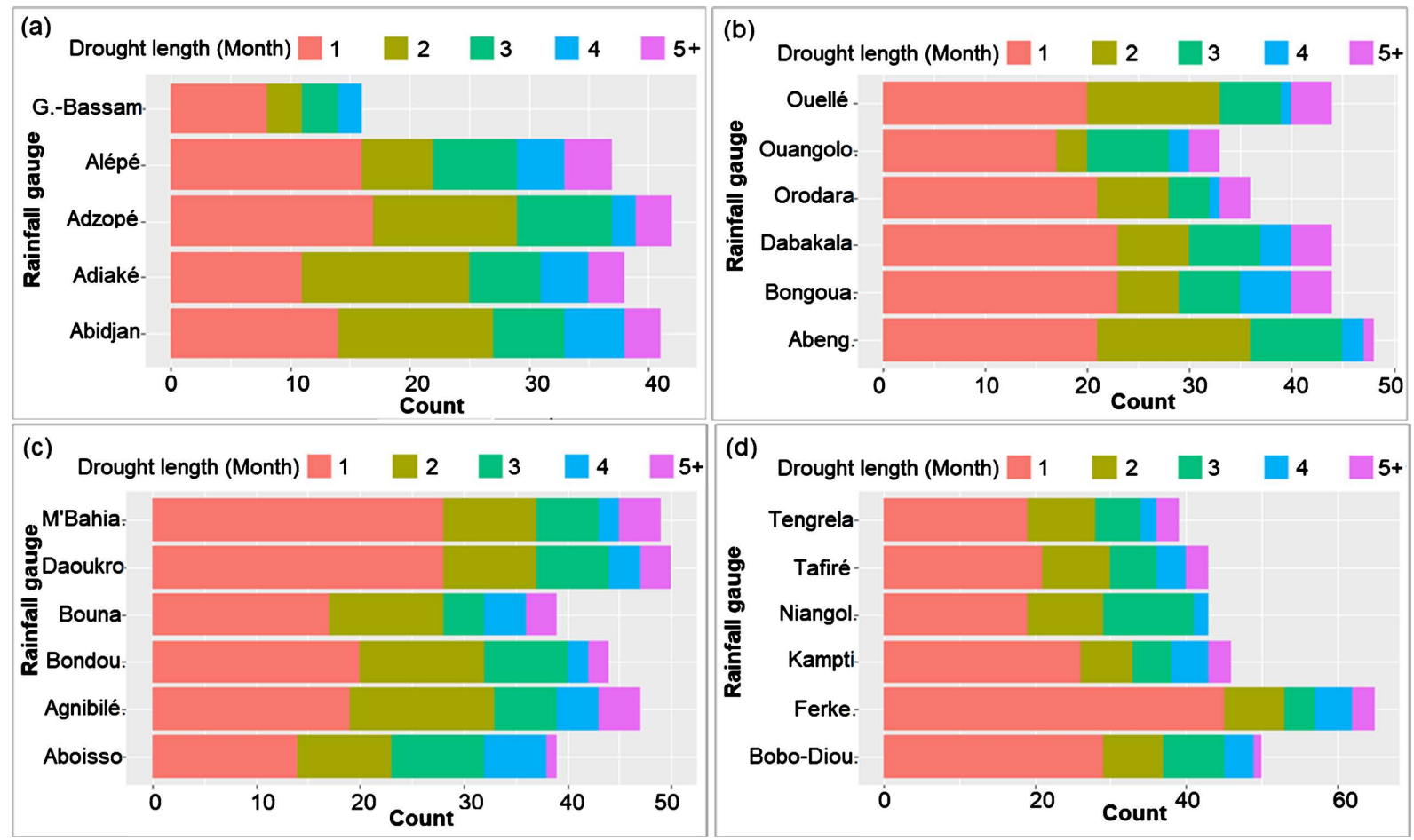

Figure 4. Rainfall drought length per gauge from 1960 to 2000 (a)-(d). 
durations. However, rainfall deficits of more than 4, and 5 months have more or less significant numbers. The stations located in the southern part of the basin (Grand-Bassam, Abidjan, Adiaké, Adzopé, Alépé, and Aboisso) are characterized by an average of 40 months of drought over the study period. In comparison, almost all stations in the central part (transitional equatorial climate) and the northern part (tropical climate) have more than 40 months of drought, with the exception of the gauges of Bouna, Tengréla, Ouangolodougou and Orodara.

\subsection{Trend and Stationarity Break within SPI.3 Series}

The parametric (t-Student) and non-parametric (CUSUM) tests for breakpoint show similar results for almost all the stations studied. The same observation is made for the two trend tests (Mann-Kendall and Linear Regression), which also show similar results except for the Abengourou and Ferkessédougou stations (Table 3). Indeed, for these two series of SPI.3, the linear regression test is insignificant while that of Mann-Kendall is significant at the risk of error $\alpha=0.05$. However, statistic tests used would be robust for the analysis of the temporal sets because of the concordance between them. The stations as a whole show declining trends in SPI.3 values, hence a propensity for drought.

It should be noted that only the Ouellé gauge at the center of the basin and those of Tafiré and Ferkessédougou in the northern part are known an increase in SPI.3 values, resulting in increased humidity. This indicates a resumption of rainfall in these localities. The break dates in the series are variable. The break observed before 1970 concerns the Orodara, Grand-Bassam, Bouna and Kampti stations. Between 1970 and 1980, breaks were observed in the series of Ouangolodougou, Abengourou, Dabakala, Adzopé, Bondoukou, Agnibilékrou, M’Bahiakro stations.

\subsection{Spatial Distribution of SPI.3 Trends before and after Homogeneity Break-Points}

Climate variability impact on the spatio-temporal distribution of drought is estimated across the Sen's slopes calculated for SPI.3 time series before and after the break-points (Figure 5). At the basin scale, Sen's slopes are low (hundredth order). Times series from 1960 to the various break dates record negative slopes between -0.01 and 0.00 characteristic of a slight drought trend for most of the catchment (Figure 5(a)). Only the northeastern part of the basin experienced an increase in humidity during this period, with a higher level of humidity in the extreme northeast around the towns of Kampti and Orodara, where the slopes of Sen fluctuate between 0.010 and 0.020 . In contrast to all the catchments, the extreme north will experience a higher extend to drought (Sen's Slope range -0.010 to -0.005 ) from 1960 to the different break dates in the SPI.3 series.

After the break-up periods (Figure 5(b)), almost the entire northern part of the catchment area will remain slightly wet with Sen's slopes between 0.000 and 0.005: in the extreme north, there will be an increase in the wetness trend at the 
Table 3. Break date and trend tests of SPI.3 series from rainfall gauges.

\begin{tabular}{|c|c|c|c|c|c|c|c|c|}
\hline \multirow{3}{*}{ Station } & \multicolumn{4}{|c|}{ Break test } & \multicolumn{4}{|c|}{ Trend test } \\
\hline & \multicolumn{2}{|l|}{ CUSUM } & \multicolumn{2}{|c|}{ Student } & \multicolumn{2}{|c|}{ Mann-Ken. } & \multicolumn{2}{|c|}{ Linear reg. } \\
\hline & $V k$ (break date) & $\alpha=5 \%$ & $t$ & $\alpha=5 \%$ & $Z$ & $\alpha=5 \%$ & $t$ & $\alpha=5 \%$ \\
\hline Orodara & 33 (1966) & 30 & 4.29 & 2.56 & -1.88 & 1.71 & -2.01 & 1.90 \\
\hline Ouangolo. & 33 (1976) & 30 & 3.8 & 2.49 & -1.99 & 1.93 & -2.11 & 1.92 \\
\hline Abengourou & $31(1970)$ & 30 & 3.65 & 2.57 & -1.86 & 1.61 & $-1.60^{\mathrm{b}}$ & 1.68 \\
\hline Ouellé & $30(1986)$ & 27 & -3.03 & 2.53 & 1.69 & $1.64^{\mathrm{a}}$ & 1.91 & 1.69 \\
\hline Dabakala & $51(1974)$ & 37 & 6.68 & 2.411 & -3.39 & 2.49 & -3.27 & 2.52 \\
\hline Bongouanou & 39 (1993) & 37 & -0.38 & $1.71^{\mathrm{b}}$ & $0.04^{\mathrm{b}}$ & 1.60 & $-0.13^{\mathrm{b}}$ & 1.68 \\
\hline Daoukro & $21(1998)$ & $27^{\mathrm{b}}$ & -4.41 & 2.71 & $-1.2^{\mathrm{b}}$ & 1.66 & $-1.43^{\mathrm{b}}$ & 1.62 \\
\hline Abidjan & 69 (1982) & 36 & 6.22 & 2.69 & -4.90 & 2.73 & -4.96 & 2.79 \\
\hline Adiaké & $81(1982)$ & 38 & 8.85 & 2.50 & -8.69 & 2.59 & -9.30 & 2.49 \\
\hline Alépé & 29 (1996) & 29 & 4.89 & 2.53 & -3.17 & 2.56 & -3.26 & 2.56 \\
\hline G. Bassam & $31(1966)$ & 21 & 4.81 & 2.67 & -4.09 & 2.71 & -4.22 & 2.54 \\
\hline Adzopé & $43(1980)$ & 36 & 4.05 & 2.43 & -3.34 & 2.53 & -3.32 & 2.57 \\
\hline Bouna & $19(1964)$ & 27 & 3.52 & 2.64 & -2.15 & 2.08 & -2.38 & 1.95 \\
\hline Bondoukou & $48(1980)$ & 37 & 3.62 & 2.54 & -2.45 & 1.90 & -2.44 & 1.98 \\
\hline Agnibilékrou & $48(1980)$ & 36 & 3.62 & 2.31 & -2.45 & 1.92 & -2.44 & 2.01 \\
\hline M’Bahiakro & 45 (1974) & 35 & 4.75 & 2.5 & -3.55 & 2.56 & -3.73 & 2.86 \\
\hline Aboisso & $29(1981)$ & 27 & 2.97 & 2.63 & -1.73 & 1.70 & -1.93 & 1.91 \\
\hline Tafiré & $42(1994)$ & 35 & -1.70 & 1.67 & -1.67 & $1.64^{\mathrm{a}}$ & -2.05 & 1.92 \\
\hline Tengréla & $66(1985)$ & 33 & 6.91 & 2.43 & -7.25 & 2.59 & -7.52 & 2.61 \\
\hline Ferké & 45 (1985) & 35 & -1.73 & 1.65 & 1.75 & $1.63^{\mathrm{a}}$ & $1.58^{\mathrm{b}}$ & 1.66 \\
\hline Bobo-Diou. & $43(1971)$ & 37 & 5.12 & 2.45 & -2.12 & 1.88 & -2.23 & 1.91 \\
\hline Niangoloko & 43 (1971) & 36 & 5.36 & 2.82 & -2.65 & 2.49 & -2.61 & 1.98 \\
\hline Kampti & 33 (1969) & 30 & 3.89 & 2.38 & -2.12 & 2.01 & -2.26 & 2.05 \\
\hline
\end{tabular}

a Upward trends, hence the other values are downward trends. ${ }^{b}$ Rejection of hypothesis $\mathrm{H}_{0}$ (test is not significant).

expense of the previously prevailing dryness trend (Figure 5(b)). On the other hand, the extreme north-east (Kampti and Bouna) has been characterized by a decrease in humidity as evidenced by Sen's slope values of between 0.000 and 0.005. However, this decrease in humidity does not leave any room for a propensity to drought. The southern part will remain slightly subject to normal rainfall conditions with Sen slope values between -0.005 and 0.000 . 

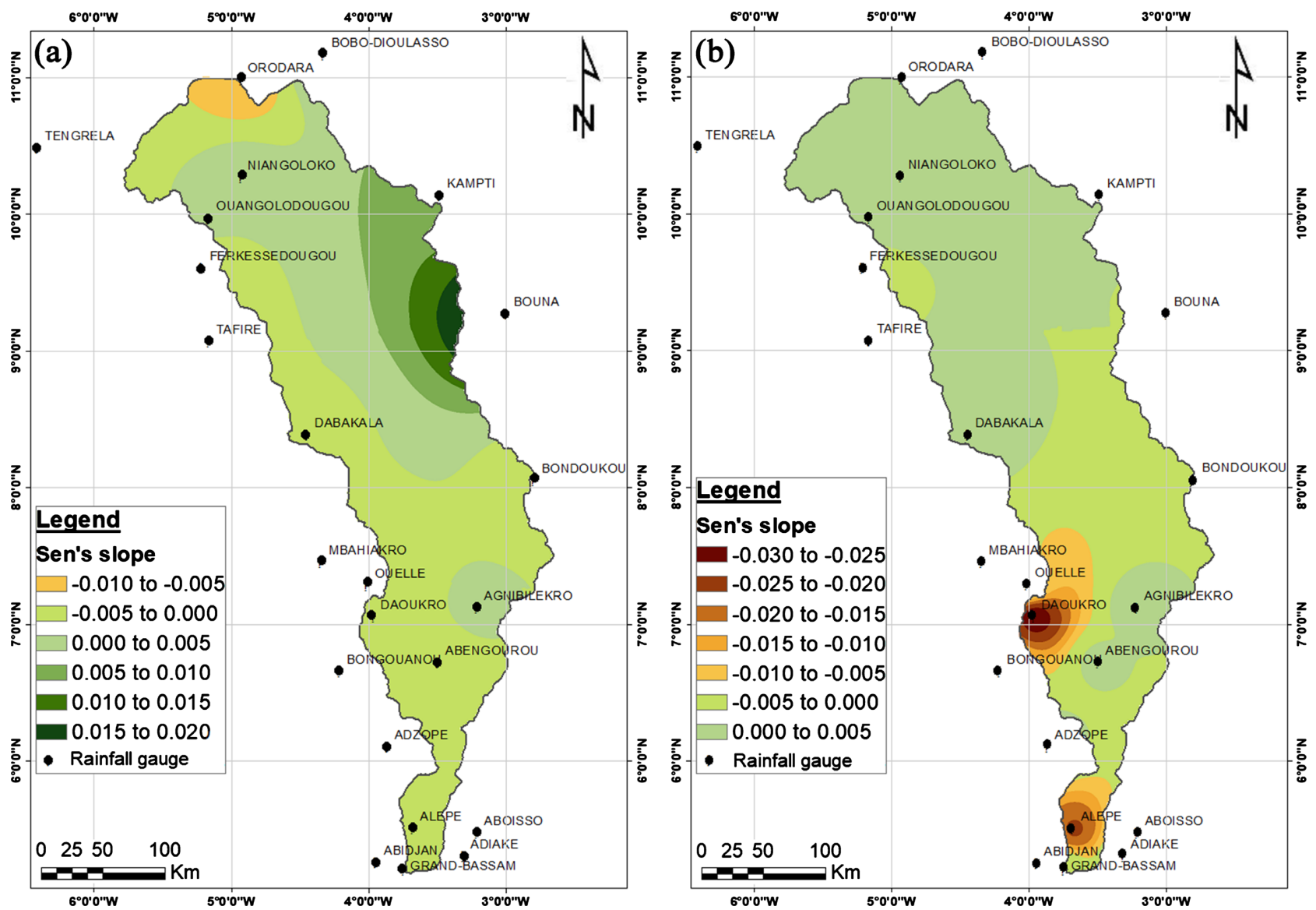

Figure 5. Spatial distribution of SPI.3 time series trend magnitude: (a) before break date; (b) after break date.

\section{Discussion}

The statistical tests used in determining trends and breaks in SPI.3 series proved to be complementary and effective. These results corroborate, once again, the performance of CUSUM (non-parametric) and t-Student (parametric) tests for breaks and Mann-Kendall (non-parametric) and Linear regression (parametric) for trends in time series as indicated by several authors [20] [27]. The temporal analysis shows a slight downward trend in SPI.3 confirming a decrease in rainfall, hence a propensity for drought in the basin. Most of the breaks observed are after the 1970s, which is the break date observed throughout sub-Saharan Africa. The Orodara, Bouna and Grand Bassam stations experienced early break-ups between 1964 and 1966, as was the case in some African basins. These years of rupture coincide with previous studies on rainfall in West Africa and Côte d'Ivoire [17]. According to [28], the drought was greater in the second half of the 1900-2013 period, i.e., from the 1970s. This trend is confirmed by several studies at the continental scale and in West Africa [29] [30]. The African continent is characterized by a decrease in rainfall accompanied by a strong spatio-temporal variability [28] [31].

During the study period (1960 to 2000), drought averaged $20 \%$ of the total catchment area. The years 1982 and 1983 are distinguished by an exceptional 
state because the drought-affected $50 \%$ or even $90 \%$ of the total area of the basin. It can be observed that the period during which the largest area of the basin has been affected corresponds to the period when the drought has been severely intense. The most representative years in terms of spatial expansion of drought, in decreasing order, are 1983, 1992, 1972, and 1982. Several drought events have been recorded through various studies in West Africa [29] [30]. These are those of 1961, 1970, 1983, 1984, 1992 and 2001. The literature reshowed the occurrence of four (4) extreme drought events in Africa during the last 50 years. Of these events, three (3) were severe. These are the episodes of 1972-1973, 1983-1984 and 1991-1992. Especially the episode from 1982 to 1983 that was affected much of the earth [32]. In Ivory Coast, specifically in the N'Zo watershed, Amani [33] showed that the droughts of the years 1968 to 1971 and 1982 to 1983 strongly influenced the rainfall variability of the years 1961 to 2000. In Ivory Coast, these dry episodes have had heavy consequences marked by fires in forests and plantations, hydroelectric power cuts, accompanied by a sharp decline in agricultural production.

In researching the natural causes of drought in Africa, some studies have focused on anthropogenic factors such as aerosol emission, land-use patterns, and continental-ocean interactions [34]. Notwithstanding the differentiation of factors from one region to another, El Niño-Southern Oscillation (ENSO) and Sea Surface Temperature (SST) remain the main factors at the continental scale. This is corroborated by the studies by [31] who, in addition to these factors, add land-atmosphere exchanges as major causes of rainfall variability in West Africa. It should be noted that few studies have been conducted in West Africa on the causes of drought [28]. However, droughts remain the warming of the oceans and the gradient of the Inter-Tropical Convergence Zone (ITCZ) [34] [35]. In Côte d'Ivoire, according to [36] and [37], the droughts of 1982 and 1983 are more strongly associated with interactions between El Niño/La Niña events and oceanic interactions via sea surface temperatures (SST).

\section{Conclusions}

This study addresses the issue of drought occurrence in the context of climate variability. In fact, current and future climatic events project a persistence of hydroclimatic extremes including drought. Drought leads to famine, epidemics and land degradation in developing countries. The main goal of this paper was to assess meteorological drought within the Comoe River watershed. However, the mean surface area of the affected Comoe watershed is about $20 \%$ during the study period (1960-2000). The period from 1980 to 1983 is characterized by exceptional events. Drought is spreading about $50 \%$ to $90 \%$ of the total area of the watershed. The year 1983 corresponds to the period during which the large surface of the basin was affected.

The study of trends in the SPI.3 series indicates a propensity for drought. The impact of rainfall variability on the spatio-temporal distribution of the drought 
is estimated through the average Sen's slopes spatialized on the time series before and after the break dates. Time series from 1960 to the various break dates recorded slopes between -0.005 and 0.00 with a slight drought trend for most of the catchment. Only the north-eastern part of the catchment area was wet. In contrast to the whole catchment area, the far north had a higher propensity to drought in the same period $(-0.010<$ Sen's Slope $<-0.005)$. After the break periods, almost the entire northern part of the basin is characterized by slight moisture with Sen's slopes between 0.000 and 0.005 . In the extreme north, an increase in the humidity trend was observed at the expense of the prevailing drought. On the other hand, the extreme north-east (Kampti and Bouna) is characterized by a decrease in Sen's slope values which fluctuated between 0.000 and 0.005 . The southern part was characterized by a normal rainfall condition with Sen's slopes between -0.005 and 0.000 .

\section{Acknowledgements}

All this work could not be done without material and financial support. I would like to express my special thanks to the facilitators of the PAES (Programme d'Appui à l'Enseignement Supérieur) in the ECOWAS region for agreeing to finance my research project.

\section{Conflicts of Interest}

The authors declare no conflicts of interest regarding the publication of this paper.

\section{References}

[1] Sen, Z. (2015) Introduction Applied Drought Modeling, Prediction, and Mitigation. Elsevier, Amsterdam, 1-41. https://doi.org/10.1016/B978-0-12-802176-7.00001-8

[2] Few, R., Ahern, M., Matthies, F. and Kovats, S. (2004) Floods, Health and Climate Change: A Strategic Review. Working Paper 63, Tyndall Centre for Climate Change Research, University of East Anglia, Norwich, 138 p.

[3] BAD (Banque Africaine de Développement) (2016) Lutte contre la Sécheresse en Afrique de L'ouest et Australe, la Bad Octroie une Enveloppe de 549 Millions. https://www.afdb.org/fr/news-and-events/afdb-group-announces-us-549-million-dr oughtresponse-package-for-eastern-and-so thern-africa-15547

[4] Nicholson, S.E., Yin, X. and Ba, M.B. (2000) On the Feasibility of Using a Lake Water Balance Model to Infer Rainfall: An Example from Lake Victoria. Hydrological Sciences Journal, 45, 75-95. https://doi.org/10.1080/02626660009492307

[5] Eriksen, S.H., Brown, K. and Kelly, P.M. (2005) The Dynamics of Vulnerability: Locating Coping Strategies in Kenya and Tanzania. The Geographical Journal, 171, 287-305. https://doi.org/10.1111/j.1475-4959.2005.00174.x

[6] Nkomo, J.C. and Bernard, G. (2006) Estimating and Comparing Costs and Benefits of Adaptation Projects: Case Studies in South Africa and the Gambia. IACC Project No. AF 47, Assessments of Impacts and Adaptations to Climate Change, International START Secretariat, Washington DC.

[7] L'Hôte, Y., Mahé, G., Some, B. and Triboulet, J.P. (2002) Analysis of a Sahelian 
Annual Rainfall Index from 1896 to 2000: The Drought Continues. Hydrological Sciences Journal, 47, 563-572. https://doi.org/10.1080/02626660209492960

[8] Kamagaté, B. (2006) Fonctionnement Hydrologique et Origines des Ecoulements sur un Bassin Versant de Milieu Tropical de Socle au Benin: Bassin Versant de la Donga (Haute Vallée de l'Ouémé). Thèse de Doctorat, Université de Montpellier II, Montpellier.

[9] Heim, R.R.J. (2002) A Review of Twentieth-Century Drought Indices Used in the United States. Bulletin of the American Meteorological Society, 83, 1149-1165. https://doi.org/10.1175/1520-0477-83.8.1149

[10] McKee, T.B., Doesken, N.J. and Kleist, J. (1993) The Relationship of Drought Frequency and Duration to Time Scales. Proceedings of the 8 th Conference on Applied Climatology, Boston, 17-22 January 1993, 179-184.

[11] Svoboda, M., Hayes, M. and Wood, D. (2012) Guide d'Utilisation de l'Indice de Précipitation Normalisé. $\mathrm{N}^{\circ} 1090$, Genève.

[12] Zargar, A., Sadiq, R., Naser, B. and Khan, F.I. (2011) A Review of Drought Indices. Environmental Reviews, 19, 333-349. https://doi.org/10.1139/a11-013

[13] Tannehill, I.R. (1947) Drought: Its Causes and Effects. Princeton University Press, Princeton. https://doi.org/10.1097/00010694-194707000-00010

[14] JICA (2001) Plan Directeur de Gestion Intégrée des Ressources en Eau en République de Côte d'Ivoire. Rapport principal, 446 p.

[15] L'Hôte, Y. (1998) Climatologie et Agro-Climatologie de la Province Extrême Nord (P.E.N.) du Cameroun. Fonds Documentaire ORSTOM, Paris, 25 p.

[16] Noufé, D. (2011) Changements Hydroclimatiques et Transformations de l'Agriculture: l'Exemple des Paysanneries de l'Est de la Côte d'Ivoire. Doctorat de l'Université de Paris 1.

[17] Goula, B.T.A., Savane, I., Konan, B., Fadika, V. and Kouadio, G.B. (2006) Impact de la Variabilité Climatique sur les Ressources Hydriques des Bassins de N'zo et N'zi En Côte d'ivoire (Afrique Tropicale Humide). Vertigo, 7, 1-12.

[18] Yao, F.Z., Reynard, E., Ouattara I., N'go, Y.A., Fallot, J.-M. and Savané, I. (2018) A New Statistical Approach to Assess Climate Variability in the White Bandama Watershed, Northern Côte d'Ivoire. Atmospheric and Climate Sciences, 8, 410-430. https://doi.org/10.4236/acs.2018.84027

[19] Hayes, M.J. (2007) Drought Indices. The Intermountain West Climate Summary, 3, 2-3.

[20] Kundzewicz, Z.W. and Robson, A.J. (2004) Change Detection in Hydrological Records-A Review of the Methodology/Revue Méthodologique de la Détection de Changements dans les Chroniques Hydrologiques. Hydrological Sciences Journal, 49, 7-19. https://doi.org/10.1623/hysj.49.1.7.53993

[21] Krishna, M.U. (2012) Studies in Low and Flood Flow Estimation for Irish River Catchments. Doctor of Philosophy of the National University of Ireland, Galway.

[22] Helsel, D.R. and Hirsch, R.M. (2002) Statistical Methods in Water Resources. United States Geological Survey Book 4, Hydrologic Analysis and Interpretation, Book 3, $524 \mathrm{p}$.

[23] De Lima, M.I.P., Carvalho, S.C.P., De Lima, J.L.M. and Coelho, M.F.E. (2010) Trends in Precipitation: Analysis of Long Annual and Monthly Time Series from Mainland Portugal. Advances in Geosciences, 25, 155-160. https://doi.org/10.5194/adgeo-25-155-2010

[24] Good, P. (1993) Permutation Tests: A Practical Guide to Resampling Methods for 
Testing Hypotheses. Springer-Verlag, Berlin, Germany. https://doi.org/10.1007/978-1-4757-2346-5 3

[25] Shahid, S. and Khairulmaini, O.S. (2009) Spatio-Temporal Variability of Rainfall over Bangladesh during the Time Period 1969-2003. Asia-Pacific Journal of Atmospheric Sciences, 45, 375-389.

[26] Pingale, S.M., Khare, D., Jat, M.K. and Adamowski, J. (2014) Spatial and Temporal Trends of Mean and Extreme Rainfall and Temperature for the 33 Urban Centers of the Arid and Semi-Arid State of Rajasthan India. Atmospheric Research, 138, 73-90. https://doi.org/10.1016/j.atmosres.2013.10.024

[27] Rai, R.K., Upadhyay, A. and Ojha, C.S.P. (2010) Temporal Variability of Climatic Parameters of Yamuna River Basin: Spatial Analysis of Persistence, Trend and Periodicity. The Open Hydrology Journal, 4, 184-210. https://doi.org/10.2174/1874378101004010184

[28] Masih, I., Maskey, S., Mussá, F.E.F. and Trambauer, P.A. (2014) Review of Droughts on the African Continent: A Geospatial and Long-Term Perspective. Hydrology and Earth System Sciences, 18, 3635-3649. https://doi.org/10.5194/hess-18-3635-2014

[29] Ouassou, A., Ameziane, T., Ziyad, A., and Belghiti, M. (2007) Application of the Drought Management Guidelines in Morocco. Options Méditerranéennes, Series B, 58, 343-372.

[30] Kasei, R., Diekkrüger, B. and Leemhuis, C. (2010) Drought Frequency in the Volta Basin of West Africa. Sustainability Science, 5, 89-97.

https://doi.org/10.1007/s11625-009-0101-5

[31] Nicholson, S.E. (2000) The Nature of Rainfall Variability over Africa on Time Scales of Decades to Millennia. Global and Planetary Change, 26, 137-158. https://doi.org/10.1016/S0921-8181(00)00040-0

[32] Wilhite, D.A. and Glantz, M.H. (1985) Understanding the Drought Phenomenon: The Role of Definitions. Water International, 10, 111-120. https://doi.org/10.1080/02508068508686328

[33] Amani, K.M. (2003) Apports des Méthodes Statistiques et Géostatistiques à l'Etude de la Variabilité Hydro-climatique dans la Région Semi-Montagneuse de Côte d'Ivoire. Cas du Bassin Versant du N'Zo. Mémoire de DEA des Sciences de la Terre, Université de Cocody.

[34] Lebel, T., Cappelaere, B., Gallea, S., Hanan, N., Kergoat, L., Levis, S., Vieux, B. Descroix, L., Gosset, M., Mougin, E., Peugeot, C. and Seguis, L. (2009) AMMA-CATCH Studies in the Sahelian Region of West-Africa: An Overview. Journal of Hydrology, 375, 3-13. https://doi.org/10.1016/j.jhydrol.2009.03.020

[35] Dai, A. (2011) Drought under Global Warming: A Review. Wiley Interdisciplinary Reviews-Climate Change, 2, 45-65. https://doi.org/10.1002/wcc.81

[36] Noufé, D. (2003) Etude des Connexions des Températures de Surface Océanique (TSO) dans le Golfe de Guinée, avec la Dynamique Atmosphérique et la Variabilité des Paramètres Climatiques sur le Littoral Ivoirien. Mémoire de DEA, Université de Cocody-Abidjan (RCI).

[37] Kouadio, K.Y. (2002) Influence des Paramètres Météo-Océaniques de l'Atlantique Tropical sur la Pluviométrie en Côte D'Ivoire. Doctorat de l'Université de CocodyAbidjan (Côte d'Ivoire). 